\title{
Pengaruh ekstrak kulit umbi bawang putih (Allium sativum L.) terhadap kadar kolesterol darah total tikus jantan galur wistar diabetes mellitus
}

\author{
Rina Wijayanti*, Abdur Rosyid, Iffa Kholishotul Izza \\ Program Studi Farmasi Fakultas Kedokteran Universitas Islam Sultan Agung Semarang \\ Jalan Kaligawe KM 4 Semarang 50012
}

\begin{abstract}
ABSTRAK
Diabetes Mellitus (DM) adalah gangguan metabolisme dikarakterisasi oleh hiperglikemia. Penderita DM dengan kadar gula darah tinggi meningkatkan resiko gangguan metabolisme lemak. Kulit umbi bawang putih mengandung alkaloid, kuinon, flavonoid, saponin, dan polifenol yang mampu menurunkan kadar gula darah. Penelitian ini bertujuan untuk mengetahui pengaruh ekstrak kulit umbi bawang putih (Allium sativum L.) terhadap kadar kolesterol total darah pada tikus jantan galur Wistar diabetes mellitus. Kulit umbi bawang putih dimaserasi menggunakan pelarut etanol $70 \%$ dengan perbandingan 1:10. Sebanyak 25 ekor tikus jantan galur wistar dibagi dalam 5 kelompok, yaitu I adalah kelompok baseline; II adalah kelompok kontrol aloksan $160 \mathrm{mg} / \mathrm{kgBB}$ intra peritoneal single dose; III, IV, dan V adalah kelompok yang diinduksi aloksan $160 \mathrm{mg} / \mathrm{kgBB}$ intra peritoneal single dose dan diberikan ekstrak kulit umbi bawang putih dengan dosis secara berturut-turut $1000 \mathrm{mg} / \mathrm{kg} \mathrm{BB}, 2000 \mathrm{mg} / \mathrm{kg}$ BB dan $4000 \mathrm{mg} / \mathrm{kg}$ BB per oral selama 14 hari. Data dianalisis menggunakan Kruskal-Wallis dan dilanjutkan Mann-Whitney. Hasil penelitian menunjukkan terdapat perbedaan yang bermakna antara kontrol negatif dengan kelompok baseline, III, IV, dan V. Ekstrak kulit umbi bawang putih pada dosis $1000 \mathrm{mg} / \mathrm{kg} \mathrm{BB}, 2000 \mathrm{mg} / \mathrm{kg} \mathrm{BB}$ dan $4000 \mathrm{mg} / \mathrm{kg}$ BB mampu menurunkan kadar kolesterol total darah pada tikus jantan galur Wistar diabetes mellitus.
\end{abstract}

Kata kunci: kolesterol, diabetes mellitus, kulit umbi bawang putih

\begin{abstract}
Diabetes Mellitus (DM) is a group of metabolic diseases characterized by hyperglycemia. DM patient with elevated levels of blood glucose increase the risk lipid metabolism disorder. Skin of garlic containcompounds of alkaloid, quinone, flavonoid, saponin, and polyphenol which can lower blood glucose level. This study objective was to explore the effect of garlic (Allium sativum L.) skin extract towards bloodtotal cholesterol levels in diabetic male Wistar rats. Skin of garlic was macerated by ethanol $70 \%$ with ratio 1:10. Twenty-five male Wistar rats was divided into 5 groups, $1^{\text {st }}$ group was baseline; $2^{\text {nd }}$ group was as aloxan control which was administered with single dose of alloxan $160 \mathrm{mg} / \mathrm{kg} \mathrm{BW}$ by intra peritoneal; $3^{\text {rd }}, 4^{\text {th }}$ and $5^{\text {th }}$ groups were induced by a single dose of alloxan $160 \mathrm{mg} / \mathrm{kg}$ BW by intra peritoneal and administered by garlic skin extract dose $1000 \mathrm{mg} / \mathrm{kg} \mathrm{BW}, 2000 \mathrm{mg} / \mathrm{kg} \mathrm{BW}$, and $4000 \mathrm{mg} / \mathrm{kg} \mathrm{BW}$ by oral for 14 days. Data was analyzed statistically with Kruskal-Wallis and Mann-Whitney.
\end{abstract}

\footnotetext{
Penulis korespondesi:

Rina Wijayanti

Program Studi Farmasi Fakultas Kedokteran Universitas Islam Sultan Agung Semarang

Jalan Kaligawe KM 4 Semarang 50012

Email: wijayanti@unissula.ac.id
} 
The results showed that there was a significant difference between the control negative group and the baseline, $3^{\text {rd }}, 4^{\text {th }}$, and $5^{\text {th }}$ groups. The garlic skin extract dose $1000 \mathrm{mg} / \mathrm{kg} \mathrm{BW}, 2000 \mathrm{mg} / \mathrm{kg} \mathrm{BW}$, and $4000 \mathrm{mg} / \mathrm{kg}$ BW could lower the blood total cholesterol levels in diabetic male Wistar rats.

Keywords: cholesterol, diabetes mellitus, the garlic skin extract

\section{PENDAHULUAN}

Diabetes Mellitus (DM) adalah gangguan metabolisme yang dikarakterisasi oleh hiperglikemia (Dipiro, et al., 2011). Pada penderita DM terjadi gangguan lemak dalam darah sehingga meningkatkan resiko dislipidemia salah satunya peningkatan kadar kolesterol dalam darah. Pasien dengan kadar gula darah tinggi pada umumnya akan mengalami gangguan metabolism lemak, yang mengakibatkan peningkatan kadar kolesterol (Agoreyo, et al., 2008). Menurut riset kesehatan dasar tahun 2013, prevalensi penyakit diabetes di Indonesia pada usia lebih dari 15 tahun sebanyak $0,1 \%$ dan meningkat sesuai bertambahnya umur, pada usia 55-64 tahun sebanyak 4,8\% penduduk Indonesia menderita DM. Prevalensi kolesterol total abnormal pada penduduk Indonesia sebesar 35,9\%, sedangkan prevalensi hiperkolesterolemia pada penderita DM yaitu $20-90 \%$ (Depkes, 2013).

Salah satu tanaman yang digunakan dalam pengobatan tradisional dalam menurunkan kolesterol adalah bawang putih. Penelitian yang dilakukan oleh Nadzifa (2010) menyimpulkan bahwa pemberian air perasan bawang lanang mampu menurunkan kadar glukosa darah mencit DM yang diinduksi streptozotocin. Hasil penelitian Priskila (2008) diperoleh kesimpulan bahwa ekstrak bawang putih mampu menurunkan kadar kolesterol total pada kelompok perlakuan. Kulit umbi bawang putih dalam penelitian yang dilakukan oleh Wijayanti dan Rosyid (2015) diketahui mengandung senyawa aktif alkaloid, kuinon, flavonoid, saponin, dan polifenol.

Penelitian ini bertujuan untuk mengetahui pengaruh ekstrak kulit umbi bawang putih (Allium sativum L.) terhadap kadar kolesterol total darah tikus jantan galur Wistar Diabetes Mellitus.

\section{METODE PENELITIAN}

\section{Alat dan Bahan}

Alat yang digunakan dalam penelitian ini adalah peralatan yang digunakan untuk pembuatan ekstrak, glukometer (merk Easy touch dengan ketelitian 1-500 $\mathrm{mg} / \mathrm{dl}$ ), peralatan untuk pengambilan sampel darah tikus, spektrofotometer UV-Vis (merk Neidolph). Bahan yang digunakan dalam penelitian ini adalah kulit umbi bawang putih yang diperoleh dari Pasar Johar Semarang, Aloksan (Grade Laboratorium-SIGMA Aldrich), CMC Na 1\% (Food Grade-PT. Brataco), Etanol 70\% (Grade Laboratorium-PT. Brataco), Aquadest (Food Grade-PT. Brataco), Reagen kit kolesterol total (Grade Analysis-Elitrol), hewan uji berupa tikus jantan galur Wistar usia $2-3$ bulan dengan berat badan $210 \pm 22 \mathrm{~g}$.

\section{Jalannya Penelitian}

Penelitian ini bersifat experimental dengan rancangan penelitian post test only control group design dengan langkah sebagai berikut :

\section{Pembuatan ekstrak kulit umbi bawang putih}

Sebanyak $1000 \mathrm{~g}$ kulit umbi bawang putih yang telah dihaluskan dimaserasi menggunakan $10000 \mathrm{ml}$ etanol 70\% selama 5 hari (setiap hari diaduk), saring menggunakan kain flannel, filtrat diuapkan di rotary evaporator pada suhu $50^{\circ} \mathrm{C}$ dengan kecepatan $100 \mathrm{rpm}$ sampai menjadi ekstrak kental Wijayanti dan Rosyid (2015). 


\section{Skrining fitokimia ekstrak kulit umbi bawang putih}

Ekstrak diuji kandungan alkaloid menggunakan reagen Mayer, Wagner, dan Dragendorff; uji tannin dan polifenol; uji saponin; uji flavonoid

\section{Pemberian induksi aloksan}

Hewan uji pada kelompok II, III, IV, dan V diberikan aloksan dengan dosis $160 \mathrm{mg} / \mathrm{kg}$ BB secara intra peritoneal single dose hingga mencapai efek Diabetes Mellitus (memerlukan waktu 3 hari). Kelompok I diberikan makan dan minum standar

\section{Pemberian ekstrak kulit umbi bawang putih}

Ekstrak kulit umbi bawang putih (EKUBP) diberikan per oral pada hewan uji kelompok III, IV, dan V dengan dosis secara berturut-turut $1000 \mathrm{mg} / \mathrm{kg} \mathrm{BB}, 2000 \mathrm{mg} / \mathrm{kg} \mathrm{BB}$ dan $4000 \mathrm{mg} / \mathrm{kg}$ BB dalam CMC Na 1\% selama 14 hari terhitung setelah tikus mengalami Diabetes Mellitus (hari ke 4 setelah induksi aloksan).

\section{Pengambilan sampel darah}

Tikus dipuasakan selama 12 jam, kemudian sampel darah diambil melalui ekor tikus pada hari ke 4 setelah pemberian aloksan, dan diukur kadar gula darah puasa menggunakan strip glucotest. Pada hari ke-15 setelah pemberian ekstrak, masing-masing hewan uji diukur kadar kolesterol total darah setelah dipuasakan $12 \mathrm{jam}$. Pengambilan darah dilakukan di vena ophtalmicus yang terletak di sudut bola mata mengarah ke belakang bola mata. Darah ditampung secara hatihati ke dalam mikrotube yang sebelumnya telah ditetesi EDTA, kemudian disentrifugasi dengan kecepatan $7000 \mathrm{rpm}$ selama 5 menit untuk mendapat filtrat yang jernih. Pengukuran kadar kolesterol total langsung dilakukan setelah semua plasma sudah dipisahkan dengan hematokrit yang terbentuk (Gustiansyah, 2012).Penetapan kadar kolesterol total dilakukan dengan metode kolorimetri enzimatik dengan kolesterol esterase, kolesterol oksidase, dan peroksidase sebagai katalisator.

\section{Analisis Data}

Data berat badan diuji menggunakan ANOVA, sedangkan data kolesterol total dilakukan uji non parametrik dengan Kruskal-Wallis dilanjutkan uji Mann-Whitney.

\section{HASIL DAN PEMBAHASAN}

Tanaman asal yang digunakan adalah bawang putih yang telah dideterminasi, bagian tanaman yang diambil adalah kulit yang menempel secara langsung pada umbi. Ekstrak yang diperoleh dalam penelitian ini dilakukan pengamatan terhadap karakteristik ekstrak serta skrining fitokimia untuk mengetahui kandungan metabolit sekunder. Hasil pengamatan karakteristik ekstrak tersaji pada Tabel I.

Tabel I. Hasil pengamatan karakteristik ekstrak kulit umbi bawang putih (Allium sativum L.)

\begin{tabular}{cc}
\hline Parameter & Hasil Pengamatan \\
\hline Organoleptik & Bentuk : Cairan kental \\
& Warna : Coklat kehitaman \\
& Bau : Khas \\
& Rasa : Pahit \\
Kadar Air & $9 \%$ \\
Rendemen & $4 \%$ \\
\hline
\end{tabular}

Nilai rendemen ekstrak kulit umbi bawang putih adalah 4\%, sedangkan pada penelitian Mulianti tahun 2014 dengan menggunakan ekstrak umbi bawang putih diperoleh rendemen 30\%. Perbedaan ini disebabkan perbedaan simplisia yang digunakan yaitu bagian kulit umbi bawang 
putih sehingga nilai rendemen kurang dari rendemen ekstrak umbi bawang putih. Besar kecilnya nilai rendemen menunjukkan keefektivan proses ekstraksi. Efektivitas proses ekstraksi dipengaruhi oleh simplisia yang digunakan, jenis pelarut sebagai penyari, ukuran partikel simplisia, metode, dan lamanya ekstraksi (Permawati, 2008).

Kadar air pada pada penelitian ini yang ditetapkan secara gravimetrik dengan penimbangan bobot tetap diperoleh nilai $9 \%$. Nilai ini menyatakan jumlah minimum kandungan air dalam bahan karena berada di atmosfer atau lingkungan udara terbuka, dengan syarat kadar air ekstrak kurang dari $10 \%$ untuk mencegah pertumbuhan kapang khamir.

Ekstrak kulit umbi bawang putih diuji skrining fitokimia untuk mengetahui senyawa aktif yang terkandung di dalam ekstrak. Hasil uji skrining fitokimia tersaji pada Tabel II. Senyawa yang ada pada ekstrak kulit umbi bawang putih sesuai dengan penelitian Wijayanti dan Rosyid (2015) yang mengatakan bahwa ekstrak kulit umbi bawang putih memiliki kandungan senyawa alkaloid, polifenol, flavonoid, saponin, dan tanin.

Tabel II. Hasil skrining fitokimia ekstrak kulit umbi bawang putih (Allium sativum L.)

\begin{tabular}{ccc}
\hline Uji & Hasil Uji & Kesimpulan \\
\hline Alkaloid & Endapan putih & Positif \\
Tanin & Hijau kehitaman & Positif \\
Polifenol & Hijau kehitaman & Positif \\
Flavonoid & Merah & Positif \\
Saponin & Berbuih & Positif \\
\hline
\end{tabular}

Pemeriksaan terhadap kadar glukosa darah dilakukan pada hari ke empat setelah induksi aloksan. Kadar glukosa darah diperiksa untuk memastikan bahwa hewan uji telah mengalami peningkatan kadar gula darah, yang hasilnya tersaji pada Gambar 1.

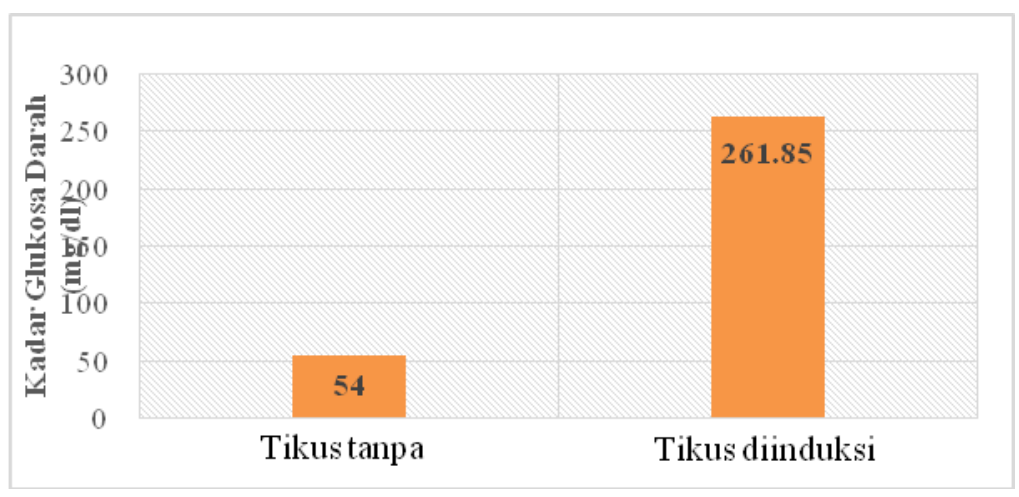

Gambar 1. Grafik Rerata Kadar Glukosa Darah hari ke 4 pasca induksi aloksan

Gambar 1 menunjukkan bahwa pada tikus yang tidak diinduksi aloksan memiliki rerata kadar glukosa darah sebesar $54 \mathrm{mg} / \mathrm{dl}$, sedangkan tikus yang diinduksi aloksan dengan dosis 160 $\mathrm{mg} / \mathrm{kg}$ BB mempunyai rerata kadar glukosa darah sebesar $261,85 \mathrm{mg} / \mathrm{dl}$. Pengukuran kadar glukosa darah dilakukan pada hari ke 4 pascainduksi aloksan, setelah tikus dipuasakan selama 12 jam. Kadar glukosa darah tikus normal yaitu $50-135 \mathrm{mg} / \mathrm{dl}$ (Kusumawati, 2004). Hasil pengukuran kadar glukosa darah seperti yang tertuang pada Gambar 1 tersebut menunjukkan bahwa telah terjadi peningkatan kadar glukosa darah pasca induksi aloksan. Peningkatan glukosa darah tersebut disebabkan aloksan dapat mendestruksi sel beta pankreas dengan sifat sebagai radikal bebas (Nurlaela, 2010). Hal senada diungkap oleh Rohilla et al., (2012) yang mengungkapkan bahwa pasca induksi aloksan terbagi menjadi 3 fase, di mana pada 1-4 jam setelah injeksi aloksan disebut sebagai fase hiperglikemia sementara, pada 6-12 jam setelah injeksi disebut sebagai fase 
hipoglikemia sementara, dan setelah 72 jam pasca induksi disebut sebagai fase hiperglikemia permanen yang diikuti gejala-gejala diabetes lain.

Penimbangan berat badan dilakukan pada hewan uji selama perlakuan dengan tujuan untuk melihat adanya perubahan berat badan pada tikus Diabetes Mellitus. Penimbangan dilakukan pada saat hari pertama sebelum induksi aloksan (H1), pada saat tikus diukur kadar glukosa darah (H4), pada saat tikus telah diberi ekstrak selama 7 hari (H11), serta sebelum tikus diambil darah untuk pengukuran kadar kolesterol total (H19). Hasil rerata berat badan tertuang pada Tabel III.

Tabel III. Hasil pengamatan rerata berat badan tikus yang diinduksi Aloksan, Ekstrak Kulit Umbi Bawang Putih (EKUBP)

\begin{tabular}{ccccc}
\hline \multirow{2}{*}{ Kelompok } & \multicolumn{4}{c}{ Rerata Berat Badan \pm SD (gram) } \\
\cline { 2 - 5 } & \multicolumn{1}{c}{ H1 } & \multicolumn{1}{c}{ H4 } & \multicolumn{1}{c}{ H11 } & H19 \\
\hline Baseline & $203 \pm 18,4$ & $199 \pm 13,9$ & $213 \pm 12,1$ & $218 \pm 12,5$ \\
Aloksan & $197 \pm 23,1$ & $197 \pm 23,1$ & $207 \pm 15,3$ & $200 \pm 11,5$ \\
Aloksan+EKUBP 1000 mg/kg BB & $181 \pm 58,5$ & $229 \pm 98,8$ & $223 \pm 41$ & $239 \pm 44,8$ \\
Aloksan+EKUBP 2000 mg/kg BB & $208 \pm 23,1$ & $182 \pm 19,1$ & $200 \pm 11,9$ & $204 \pm 13,5$ \\
Aloksan+EKUBP 4000 mg/kg BB & $223 \pm 16,1$ & $207 \pm 27,7$ & $199 \pm 13,3$ & $204 \pm 49,8$ \\
\hline
\end{tabular}

Data rerata berat badan tikus dilakukan uji one way ANOVA setelah sebelumnya telah diuji Levene test dan Shapiro-Wilk. Berdasarkan hasil uji one way ANOVA diperoleh nilai p 0,344 ( $>0,05)$, dapat disimpulkan bahwa tidak ada perbedaan bermakna antar kelompok perlakuan. Tabel III menunjukkan bahwa terjadi perubahan berat badan yang bervariatif dari hari ke 4 hingga hari ke 11 antara kelompok yang diinduksi aloksan dengan kelompok normal, namun pada hari ke 19 berat badan kelompok Aloksan mengalami penurunan, sedangkan kelompok Baseline, Aloksan+EKUBP $1000 \mathrm{mg} / \mathrm{kg}$ BB, Aloksan+EKUBP $2000 \mathrm{mg} / \mathrm{kg} \mathrm{BB}$, dan Aloksan+EKUBP $4000 \mathrm{mg} / \mathrm{kg}$ BB mengalami peningkatan berat badan dari hari sebelumnya.

Penurunan berat badan tikus kelompok aloksan pada hari ke 19 memperlihatkan bahwa induksi aloksan yang menyebabkan diabetes mellitus dapat menurunkan berat badan walaupun tidak bermakna, hal ini sesuai pada penelitian Fahri et al., tahun 2005 bahwa aloksan dapat menurunkan berat badan dengan mekanisme merusak sel pankreas yang menghentikan sintesis insulin sehingga tidak terjadi metabolisme glukosa dan berat badan dapat menurun. Perbedaan hasil yang diperoleh tiap kelompok dapat dipengaruhi oleh faktor jumlah asupan pakan standar, respon hewan uji, dan sistem kekebalan tubuh.

Perbandingan kelompok perlakuan yang diberikan EKUBP dosis $1000 \mathrm{mg} / \mathrm{kg}$ BB, 2000 $\mathrm{mg} / \mathrm{kg} \mathrm{BB}$, dan $4000 \mathrm{mg} / \mathrm{kg}$ BB memberikan hasil peningkatan berat badan yang tidak bermakna sampai hari terakhir penelitian, hal ini sesuai dengan beberapa penelitian dengan subyek manusia dan hewan, yang melaporkan bahwa flavonoid bermanfaat untuk mengendalikan berat badan (Winarsi et al., 2013). Nakagawa et al., (2004) menjelaskan bahwa flavonoid dalam licorice merangsang terjadinya diferensiasi sel adiposa manusia in vitro. Hasil ini membuktikan bahwa flavonoid dapat memberikan efek hipoglikemik abdomen, melalui aktivitas peroxisome proliferator-activated receptor (PPAR- $\gamma$ ), flavonoid mengatur metabolisme lipid yang berkaitan dengan ekspresi gen dalam hepar.

Pengukuran kadar kolesterol total dilakukan menggunakan sampel darah yang diambil melalui plexus retro orbital hewan uji pada hari ke 15 setelah pemberian ekstrak. Hasil pengukuran rerata kadar kolesterol total dapat dilihat pada Tabel IV.

Hasil pemeriksaan kadar kolesterol total darah dilakukan uji normalitas (menggunakan uji Saphiro-Wilk) dan uji homogenitas (menggunakan Levene test) yang merupakan syarat uji parametrik. Analisis data menunjukkan bahwa data tidak homogen $(\mathrm{p}=0,008)$ dan tidak normal $(\mathrm{p}=0,025)$, sehingga dilakukan uji non parametrik dengan uji Kruskal-Wallis (diperoleh $\mathrm{p}=0,000$ ) dan dilanjutkan uji Mann-Whitney. 


\section{Tabel IV. Hasil pengamatan rerata kadar kolesterol total darah tikus yang diinduksi Aloksan, Ekstrak Kulit Umbi Bawang Putih (EKUBP)}

\begin{tabular}{cc}
\hline Kelompok & Rata-Rata \pm SD (mg/dl) \\
\hline Baseline & $80,384 \pm 3,49$ \\
Aloksan & $99,472 \pm 6,83^{(\mathrm{b})}$ \\
Aloksan+EKUBP $1000 \mathrm{mg} / \mathrm{kg} \mathrm{BB}$ & $75,474 \pm 1,38^{(\mathrm{a})(\mathrm{b})}$ \\
Aloksan+EKUBP $2000 \mathrm{mg} / \mathrm{kg} \mathrm{BB}$ & $62,41 \pm 9,19^{\text {(a) (b) }}$ \\
Aloksan+EKUBP $4000 \mathrm{mg} / \mathrm{kg} \mathrm{BB}$ & $54,644 \pm 4,55^{\text {(a) (b) }}$ \\
\hline Keterangan : ${ }^{(\text {a) }}=$ berbeda bermakna dengan kelompok Aloksan \\
${ }^{\left({ }^{b}\right)}=$ berbeda bermakna dengan kelompok Baseline
\end{tabular}

Perbandingan kelompok Baseline dengan kelompok Aloksan menunjukkan perbedaan bermakna yang berarti aloksan dapat meningkatkan kadar kolesterol total darah dengan mekanisme pembentukan oksigen reaktif untuk merusak sel beta pankreas dalam mensintesis insulin sehingga mempengaruhi metabolisme lemak (Nugroho, 2013). Kondisi DM menyebabkan peningkatan profil lipoprotein dibandingkan tikus normal (Wahyudi et al., 2015).

Analisis data menunjukkan terdapat perbedaan yang bermakna antara kelompok Aloksan+EKUBP 1000 mg/kg BB, Aloksan+EKUBP 2000 mg/kg BB, dan Aloksan+EKUBP 4000 $\mathrm{mg} / \mathrm{kg}$ BB dengan kelompok Aloksan. Hal ini berarti bahwa EKUBP mampu menurunkan kadar kolesterol total pada tikus diabetes mellitus. Kelompok Aloksan+EKUBP $1000 \mathrm{mg} / \mathrm{kg} \mathrm{BB}$, Aloksan+EKUBP $2000 \mathrm{mg} / \mathrm{kg} \mathrm{BB}$, dan Aloksan+EKUBP $4000 \mathrm{mg} / \mathrm{kg}$ BB berbeda bermakna dengan kelompok Baseline. Hal ini menunjukkan bahwa pemberian ekstrak dengan dosis bertingkat dapat menurunkan kadar kolesterol hingga batas normal kadar kolesterol pada tikus yaitu $10-54 \mathrm{mg} / \mathrm{dl}$ (Harini, 2009).

Kemampuan EKUBP dalam menurunkan kadar kolesterol total karena mengandung senyawa saponin, alkaloid, dan flavonoid. Saponin dapat membentuk ikatan kompleks yang tidak larut dengan kolesterol sehingga kolesterol tidak dapat diserap oleh usus, dan flavonoid dapat menetralkan radikal bebas yang melindungi pankreas (Chen et al., 2001).

Saponin mempunyai kemampuan untuk menurunkan kadar kolesterol, diduga berkaitan dengan sifat saponin yang dapat membentuk senyawa kompleks atau membentuk misel campuran antara saponin, kolesterol dan asam empedu (Son et al., 2007). Saponin dapat menghambat penyerapan kolesterol dan asam empedu di usus, sehingga memacu sintesis kolesterol di hati yang dikonversi menjadi asam empedu yang kemudian disekresikan ke usus. Hal ini menyebabkan sekresi oleh feses lebih besar dibandingkan penyerapan oleh usus, Saponin tidak terserap di usus, tetapi di metabolisme dalam usus besar menjadi aglikon saponin dan gula oleh mikroflora $(\mathrm{Hu}$ et al., 2004), Saponin dan asam empedu merupakan senyawa amfifilik ada bagian yang larut dalam air dan ada bagian yang larut dalam lemak. Dalam larutan terbentuk misel antara gugus hidrofobik dari triterpen atau steroid bergabung sehingga membentuk seperti koin kecil. Saponin tidak dapat diserap oleh usus melalui mekanisme ASBT (Apical sodium codependend bile acid transporter) pada sirkulasi enterohepatik dan lebih banyak diekskresikan lewat feses sehingga asam empedu feses meningkat (Bogoriani, 2015), dengan mekanisme tersebut ekstrak kulit umbi bawang putih dapat digunakan sebelum makan untuk mengoptimalkan pengaruh ekstrak kulit umbi bawang putih dalam menurunkan kadar kolesterol total pada diabetes mellitus.

Senyawa alkaloid dalam kulit umbi bawang putih juga mempunyai peranan dalam menurunkan kadar kolesterol melalui mekanisme penghambatan aktivitas enzim lipase pankreas sehingga meningkatkan sekresi lemak melalui feses, akibatnya penyerapan lemak oleh hati terhambat sehingga tidak diubah menjadi kolesterol (Astiyandani et al., 2010). Dengan pemberian ekstrak yang mengandung senyawa saponin, flavonoid, dan alkaloid dapat digunakan untuk menurunkan kadar kolesterol pada hewan uji yang menderita diabetes. 


\section{KESIMPULAN}

Ekstrak kulit umbi bawang putih pada dosis $1000 \mathrm{mg} / \mathrm{kg} \mathrm{BB}, 2000 \mathrm{mg} / \mathrm{kg}$ BB dan 4000 $\mathrm{mg} / \mathrm{kg}$ BB mampu menurunkan kadar kolesterol total darah pada tikus jantan galur Wistar diabetes mellitus.

\section{UCAPAN TERIMAKASIH}

Ucapan terima kasih penulis haturkan kepada Universitas Islam Sultan Agung Semarang yang telah mendanai penelitian ini.

\section{DAFTAR PUSTAKA}

Agoreyo, F.O., Agoreyo, B.O., Onuorah M.N., 2008, Effect of aqueous extract of Hibiscus sabdariffa and Zingiber officinale on blood cholestrol and glucose level of rats, African Journal of Biotehnology.7, (21): 3949-3951.

Astiyandani, P. G., Permana, A. W., Vedayanti, P. D., Laraviyanti, I. D, 2010, Uji klinis in vivo pengaruh konsumsi daluman (Cyclea barbata) terhadap penurunan kadar gula darah pada tikus wistar jantan dengan diabetes mellitus tipe 2, IPTEKMA, 2 (1): 1-6.

Bogoriani, N.W., 2015, Saponin daun andong (Cordyline terminalis Kunth) menurunkan kolesterol plasma dengan meningkatkan ekskresi kolesterol dan asam empedu feses pada tikus wistar serta membentuk kompleks dengan kolesterol secara in vitro, Disertasi, Denpasar: Universitas Udayana.

Chen, T.H., Liu, J.C., Chang, J.J., Tsai, M.F., Hsieh, M.H., Chan, P., 2001, The in vitro inhibitory effect of flavonoid astilbin on 3-hydroxy-3-methylglutaryl coenzyme A reductase on Vero cells, Departemen Kesehatan Republik Indonesia, 2013, Riset Kesehatan Dasar 2013, Jakarta: Badan Penelitian dan Pengembangan Kesehatan RI, 64(7):382-387.

Dipiro, J.T., Posey, M.L., Wells, B.G., Matzke, G.R., Yee, G.R., Talbert, R.L., 2011, Pharmacoterapy A Pathophysiologic Approach $8^{\text {th }}$ Edition, Amerika: Access Pharmacy Mc Graw Hill.

Fahri, C., Sutarno, Listyawati, S., 2005, Kadar glukosa dan kolesterol total darah tikus putih (Rattus norvergicus L.) hiperglikemik setelah pemberian ekstrak metanol akar meniran (Phylanthus niruri L.), Biofarmasi, 3 (1): 1-6.

Gustiansyah, R.J., 2012, Efek susu kacang kedelai (Glycine max L.) terhadap kadar asam urat darah tikus putih jantan yang diinduksi kalium oksalat, Skripsi. Jakarta: Universitas Indonesia.

Harini, M.D., 2009, Blood cholesterol level of hypercholesterolemia rat (Rattus novergicus) after VCO treatment, Journal Bioscience, 1 (2): 53-58.

Hu, J., Zheng, Y., Hyde, W., 2004, Human fecal metabolism soya saponin, I. Journal Agric.Food Chem. 52: 2689-2696.

Kusumawati, D., 2004, Deals with Animal Model in Laboratory (Write In Bahasa Indonesia), Yogyakarta: Gajah Mada University Press.

Nadzifa, I., 2010, Pengaruh air perasan bawang lanang (Allium sativum) terhadap kadar glukosa darah dan gambaran histologi pankreas pada mencit (Mus muculus) diabetes mellitus, Skripsi, Universitas Islam Negeri, Malang.

Nakagawa, K., Kishida, H., Arai, N., Nishiyama, T., Mae, T., 2004, Licorice flavonoid suppress abdominal fat accumulation and increase in blood glucose level in obese diabetic KK-A(y) mice, Biological and Pharmaceutical Bulletin, 27:1775-1778.

Nugroho, C.A., (2013), Aktivitas hipokolesterolimik ekstrak rosela (Hibiscus sabdariffa) pada tikus putih diabetes, Widya Warta. I (1):1-14

Nurlaela, 2010, Pengaruh pemberian eksstrak bungan rosella (Hibiscus sabdariffa L.) terhadap penurunan kadar gula darah tikus putih yang diinduksi aloksan, Skripsi, Surakarta: Universitas Sebelas Maret.

Permawati, M., 2008, Karakterisasi ekstrak air daun gandarusa (Justicia gendarussa burn F.) dan pengaruhnya terhadap kadar asam urat plasma tikus putih jantan yang diinduksi kalium oksonat, Skripsi, Depok: Universitas Indonesia. 
Priskila, M., 2008. pengaruh pemberian ekstrak bawang putih (allium sativum, linn.) terhadap penurunan rasio antara kolesterol total dengan kolesterol HDL pada tikus putih (Rattus norvegicus) Yang Hiperkolesterolemik, Surakarta: Fakultas Kedokteran Universitas Sebelas Maret.

Rohilla, Angkur and Ali, Shahjad, 2012, Alloxan induced diabetes : Mechanism and effect, International Journal of Research in Pharmaceutical and Biomedical Science, 3 (2) : 273280.

Son, I. S., Kim, J.H., Sohn, H.Y., Kim, J. S., Kwon C. S., 2007, Antioxidative and hypolidemic effect of diosgenina steroidal saponin of yam (Dioscorea spp.) on high cholesterol fed rats, Bioschi Biotechnol Biochem, 7(12):3063-3071.

Wahyudi, T., Widyastuti, S.K., Suarsana, N., 2015, Profile lipoprotein plasma rat in conditions of hyperglycemia, Indonesia Medicus Veterinus 4(2):116-121.

Wijayanti, R. dan Rosyid, 2015, Efek ekstrak kulit umbi bawang putih (Allium sativum L.) terhadap penurunan kadar glukosa darah pada tikus putih jantan galur wistar yang diinduksi aloksan, Jurnal Ilmu Farmasi \& Farmasi Klinik, 12(1): 47-52.

Winarsi, H., Sasongko, N.D., Purwanto, A., Nuraeni, I., 2013, Ekstrak daun kapulaga menurunkan indeks atherogenik dan kadar gula darah tikus diabetes induksi aloksan, Agritech 33 (3): 273-280. 